\title{
List of Contributors
}

PROFESSOR ZENON BAŃKOWSKI is Emeritus Professor of Legal Theory at the University of Edinburgh.

PROFESSOR ALEXANDER BROADIE is Emeritus Professor of Logic and Rhetoric at the University of Glasgow.

PROFESSOR JOHN W CAIRNS is Professor of Legal History at the University of Edinburgh.

DR MAKSYMILIAN DEL MAR is Lecturer in Legal and Social Philosophy at Queen Mary, University of London.

DR JULIE DICKSON is Fellow and Lecturer in Law at Somerville College, Oxford.

PROFESSOR HeCtor MaCQueEn is Professor of Private Law at the University of Edinburgh and a Scottish Law Commissioner.

PROFESSOR GERRY MAHER is Professor of Criminal Law at the University of Edinburgh.

PROFESSOR DREW SCOTT is Professor of European Union Studies at the University of Edinburgh.

PROFESSOR JOANNE SCOTT is Professor of European Law at University College London.

PROFESSOR WILLIAM STORRAR is Director of the Center of Theological Inquiry, Princeton.

PROFESSOR NEIL WALKER is Regius Professor of Public Law and the Law of Nature and Nations at the University of Edinburgh. 